\title{
The importance of transmethylation reactions to methionine metabolism in sheep: effects of supplementation with creatine and choline
}

\author{
BY G. E. LOBLEY, A. CONNELL AND D. REVELL* \\ Rowett Research Institute, Bucksburn, Aberdeen AB2 9SB
}

(Received 12 August 1994-Revised 19 January 1995-Accepted 11 May 1995)

\begin{abstract}
The influence of administering the methylated products choline and creatine on methionine irreversibleloss rate (ILR) and recycling from homocysteine has been investigated in sheep fed close to energy and $\mathrm{N}$ equilibrium. Two methods to estimate methionine recycling were compared. The first involved $\left[\mathrm{U}-{ }^{13} \mathrm{C}\right]$ methionine infused as part of a labelled amino acid mixture obtained from hydrolysed algal protein. In this approach the isotope dilution of methionine with all five $C$ atoms labelled $(m+5)$ will represent the ILR which does not recycle through homocysteine, while that which includes molecules with $\mathrm{C}$-1C-4 labelled will allow for loss of the labelled methyl (5)-C atom and replacement by an unlabelled moiety in the remethylation of homocysteine. The second method involved a combined infusion of $\left[1^{-13} \mathrm{C}\right]-$ and [S-methyl- ${ }^{2} \mathrm{H}_{3}$ ]methionine. These two approaches gave similar data for methionine ILR which does not include label recycled to the amino acid from homocysteine but differed for recycled methionine fluxes. Consequently the two procedures differed in the calculated extent of homocysteine methylation under control conditions ( $6 \mathrm{v} .28 \%$ ). These extents of remethylation are within the range observed for the fed human subject, despite the fact that fewer dietary methyl groups are available for the ruminant. Using combined data from the infusions, significant depression of methionine recycling occurred in blood $(P<0.05)$, with a similar trend for plasma $(P=0.077)$, when choline plus creatine were infused. Wool growth, assessed by intradermal injection of ${ }^{35}$ S]cysteine, was not altered by supplementation with the methylated products. From changes in the label pattern of free methionine in aortal, hepatic portal and hepatic venous blood during $U-{ }^{13} \mathrm{C}$-labelled algal hydrolysate infusion, the major sites of homocysteine remethylation appear to be the portal-drained viscera and the liver. This was confirmed by analysis of free methionine enrichments in various tissues following dual infusion of $\left[1-{ }^{13} \mathrm{C}\right]-$ and $[\mathrm{S}-$ methyl- ${ }^{2} \mathrm{H}_{3}$ ]methionine, with the greatest activities occurring in rumen, jejunum and liver. Of the nonsplanchnic tissues examined, only kidney exhibited substantial methionine cycling; none was detected in muscle, heart, lung and skin. The implications of methyl group provision under net production conditions are discussed.
\end{abstract}

Methionine: Methylation: Stable isotopes: Wool growth

Methionine plays a crucial role in mammalian metabolism: first, as an essential amino acid; second, as a precursor of cysteine biosynthesis; third, as the key intermediate in methyl group transfer. Over 100 methylation reactions involving methionine are known, including the synthesis of key metabolites (e.g. phosphatidylcholine, creatine, carnitine etc.) as well as regulation of DNA activity and oncogene status. Methionine is converted to $\mathrm{S}$ adenosylmethionine (SAM), the methyl group donor, and then to homocysteine to form one part of a substrate cycle. The back reaction involves either betaine or tetrahydrofolate as the provider of $\mathrm{a} \mathrm{C}_{1}$ unit to convert homocysteine to methionine (Finkelstein \& Martin,

* Present address: Faculty of Agriculture, University of Western Australia, Nedlands, Perth, W. Australia, Australia. 
1984). In human subjects, methyl group flux through SAM has been calculated as more than double methionine intake and, therefore, considerable remethylation of homocysteine is required (Mudd \& Pool, 1975). The problem may be even greater for the ruminant because many precursors or products of transmethylation present in the diet are destroyed by rumen microbial action, e.g. trimethyl choline is catabolized to monomethyl betaine (Neill et al. 1979). Methionine flux through the substrate cycle may be increased, therefore, to maintain adequate supplies of SAM. Both methionine and homocysteine, when present in large quantities, are toxic to cells and accumulation of either may be prevented by two alternative catabolic routes: the methionine transamination sequence (Benevenga et al. 1983) and homocysteine entry into the trans-sulphuration pathway (Finkelstein \& Martin, 1984). Consequently, temporal imbalances in the supply of either methyl group acceptors or donors may result in stimulation of net methionine catabolism and, thus, contribute to the amino acid often being limiting for ruminants fed on forages.

Such considerations raise three important questions. First, are the rates of methylation of homocysteine relative to methionine flux greater in the ruminant than the nonruminant? Second, does provision of supplemental methyl group acceptors reduce homocysteine formation from methionine? Third, can this then lead to reduced methionine catabolism and, thus, an enhanced availability for protein synthesis? Aspects of these questions have been addressed in the current study by examination of changes in ovine methionine flux in response to intravenous infusion of choline plus creatine.

\section{MATERIALS AND METHODS}

\section{Animals and surgical preparations}

The data for the current study were collected from the four sheep, prepared with vascular catheters across the portal-drained viscera, liver and into the jugular veins, reported elsewhere (Lobley et al. 1996), which includes details of ration, intake and the frequency of feeding.

\section{Experimental}

The main procedures have been described elsewhere (Lobley et al. 1996). Briefly, the four sheep were each subjected to two treatments which were alternated between animals with $14 \mathrm{~d}$ between each treatment. Treatment 1 consisted of daily infusions of a mixture of lysine $(1.5 \mathrm{~g})$ and histidine $(0.5 \mathrm{~g})$ dissolved in sterile saline $(8.9 \mathrm{~g} \mathrm{NaCl} / 1)$ into the mesenteric vein at a rate of $20 \mathrm{~g} / \mathrm{h}$, and a similar quantity of sterile saline into the jugular vein. The infusion of lysine and histidine was to increase the possibility that methionine would be the first limiting of the essential amino acids. In treatment 2 , creatine $(1.0 \mathrm{~g} / \mathrm{d})$ was added to the amino acid infusate while choline bitartrate $(0.5 \mathrm{~g}$ choline equivalent $/ \mathrm{d})$ was infused into the jugular vein. Substantial choline and phospholipid secretion occurs in bile, with much recovered by re-absorption from the gastrointestinal tract (GIT), but to minimize activation of this secretion-absorption loop the choline was infused into the jugular vein and, thus, allowed better availability to the peripheral tissues. All infusates were adjusted to $\mathrm{pH} 7 \cdot 4$. Each treatment infusion was continued for $8 \mathrm{~d}$ and on day 5 the equivalent of $1 \mathrm{~g} \mathrm{U}-{ }^{13} \mathrm{C}$-labelled algal hydrolysate was infused via a second jugular catheter for $10 \mathrm{~h}$ and hourly integrated blood samples taken over the last $4 \mathrm{~h}$ of infusion, from the aorta, the hepatic portal vein and hepatic vein (Lobley et al. 1996). On day 8 the sheep received a second continuous infusion into the jugular vein; this involved an equimolar mixture (each $0.38 \mathrm{mmol}$ in $200 \mathrm{~g}$ sterile saline) of $\left[1-^{13} \mathrm{C}\right]$ methionine (99 atom \%; MSD Isotopes, Montreal, Canada) and [S-methyl- ${ }^{2} \mathrm{H}_{3}$ ] methionine $[98$ atom \% ; Tracer Technologies Inc., Somerville, MA, USA) plus $40000 \mathrm{IU}$ heparin. Infusion rate was $0.038 \mathrm{mmol} / \mathrm{h}$ and 
arterial blood only was collected as hourly integrated samples over the last $4 \mathrm{~h}$ of infusion. Blood samples for determination of natural abundance (i.e. 'background') were taken $24 \mathrm{~h}$ before the start of each infusion of stable isotopes.

As an index of changes in methionine status, wool growth was measured by radiolabelling of wool fibres with intradermal injections of $\left[{ }^{35}\right.$ S $]$ cysteine (Aurousseau et al. 1993) during treatment periods and the intervening intervals. A minimum of $5 \mathrm{~d}$ was allowed between successive injections.

In order to examine tissue contributions to methylation of homocysteine, short infusions $(3 \mathrm{~h})$ of equimolar amounts of $\left[1-{ }^{13} \mathrm{C}\right]$ methionine and $\left[\mathrm{S}-\mathrm{methyl}-{ }^{2} \mathrm{H}_{3}\right]$ methionine $(0.038 \mathrm{mmol} / \mathrm{h})$ were performed while the animals were infused with just lysine and histidine. At the end of infusion the animals were killed by an intravenous injection of pentabarbitone and samples of rumen, jejunum, liver, $m$. longissimus dorsi, heart, kidney, lung and skin were rapidly excised and frozen in liquid $\mathbf{N}_{2}$.

\section{Analyses}

Methionine in blood and plasma from both stable isotope infusions was processed for gas chromatograph-mass spectrometry (GCMS; Trio-1, VG Masslab Ltd, Crewe) as the $t$-butyldimethylsilyl derivative (Calder \& Smith, 1988), using electron-impact conditions. Fragment ions were monitored at $\mathrm{m} / \mathrm{z}$ of 320,324 and 325 for $\left[\mathrm{U}-{ }^{13} \mathrm{C}\right.$ ]methionine (equivalent to $\mathrm{m}+0, \mathrm{~m}+4$ and $\mathrm{m}+5$ forms of the fragment) and 320,321 and 323 for the infused mixture of $\left[1-{ }^{13} \mathrm{C}\right]$ - and $\left[\mathrm{S}-\mathrm{methyl}-{ }^{2} \mathrm{H}_{3}\right]$ methionine. Appropriate corrections were applied for interference between fragment ions (Campbell, 1974) and the data expressed as molar \% excess (mpe) based on:

$$
100 \times\left(\mathbf{R}_{\mathrm{s}}-\mathbf{R}_{\mathrm{o}}\right) /\left(1+\mathrm{R}_{\mathrm{s}}-\mathrm{R}_{\mathrm{o}}\right),
$$

where $\mathrm{R}_{\mathrm{s}}$ and $\mathrm{R}_{\mathrm{o}}$ are $(\mathrm{m}+n):(\mathrm{m}+0)$ ions in the sample and background (natural abundance) respectively and $n$ is the number of labelled atoms in the methionine (i.e. 1, 3, 4 or 5). Tissue samples were homogenized in the frozen state in approximately 5 vol. cold water and protein precipitated by addition of sulphosalicylic acid $(480 \mathrm{~g} / \mathrm{l})$ to a final concentration of $70 \mathrm{~g} / \mathrm{l}$. The supernatant fraction was then desalted and treated as for plasma samples (Calder \& Smith, 1988).

\section{Calculations}

The irreversible-loss rates (ILR) of $\left[1-{ }^{13} \mathrm{C}\right]$ - and $\left[S-\right.$ methyl $\left.-{ }^{2} \mathbf{H}_{3}\right]$ methionine were calculated as:

$$
\left[\left(I_{i} / E_{m}\right)-1\right] \times I_{r},
$$

where $I_{i}$ and $I_{r}$ are the enrichments (mpe) and rate of infusion $(\mu \mathrm{mol} / \mathrm{h})$ of methionine in the infusate and $\mathrm{E}_{\mathrm{m}}$ is the mpe of either free $\left[1-{ }^{3} \mathrm{C}\right]-$ or $\left[\mathrm{S}-\mathrm{methyl}-{ }^{2} \mathrm{H}_{3}\right]$ methionine in blood or plasma.

For comparison with the ILR of $\left[1{ }^{13} \mathrm{C}\right]$ methionine that determined from the U${ }^{13} \mathrm{C}$-labelled algal infusate was based on the relative enrichment determined from the $\mathrm{m} / \mathrm{z}$ values (Lobley et al. 1996), i.e.:

$$
[(\mathrm{m}+4)+(\mathrm{m}+5)] /[(\mathrm{m}+0)+(\mathrm{m}+4)+(\mathrm{m}+5)] .
$$

These fluxes both involve the flows of non-methyl-C and include the four methionine-C atoms which are retained within the methionine $\leftrightarrow$ homocysteine cycle. For data on the ILR which monitors the methyl-C, and which thus corresponds to [S-methyl- ${ }^{2} \mathbf{H}_{3}$ ]methionine infusions, the relative enrichment used was:

$$
[m+5] /[(m+0)+(m+4)+(m+5)] \text {. }
$$


The proportion of methionine formed by methylation of homocysteine was assessed by two approaches. First, with $\left[\mathrm{U}^{-13} \mathrm{C}\right]$ methionine, transmethylation via SAM would lead to loss of one $\mathrm{C}$ atom and formation of homocysteine which, if remethylated, would yield methionine with only four of the five $\mathrm{C}$ atoms labelled; the probability of incorporation of $a^{13} \mathrm{CH}_{3}$ group being considered remote, due to isotope-dilution effects. The original algal infusate contained no $(\mathrm{m}+4)$ methionine (and was $>99$ molar $\%(\mathrm{~m}+5)$ methionine) and, therefore, any present in biological fluids must have arisen via the transmethylationremethylation reactions. Thus, the value for $\mathrm{m} / \mathrm{z}$ ions $324: 325$ will represent the minimum proportion of methionine ILR recycled from homocysteine. The value is a minimum because an $(\mathrm{m}+4)$ methionine molecule re-entering the transmethylation-remethylation cycle will not be altered further and, thus, by the current approach cannot be detected as having reparticipated in the methionine $\leftrightarrow$ homocysteine reaction. Due to the low frequency of production of $(\mathrm{m}+4)$ molecules (less than 1 in 500) the probability, and thus the associated error, of such reactions occurring is small.

For the second calculation the ILR of $\left[\mathrm{S}-\right.$ methyl $\left.-{ }^{2} \mathrm{H}_{3}\right]$ methionine should exceed that of $\left[1-{ }^{13} \mathrm{C}\right]$ methionine by the extent of methylation of homocysteine because, by analogous reasoning to that mentioned previously, the methyl group will be lost in the production of homocysteine from SAM, and the probability of a labelled moiety being reincorporated during formation of the amino acid is considered to be low. Label at the C-1 position will be conserved in the cycle, methionine $\leftrightarrow$ homocysteine, and thus will underestimate the ILR of the amino acid. Fluxes based on $\left[(\mathrm{m}+5)-\mathrm{U}-{ }^{13} \mathrm{C}\right]$ and $\left[\mathrm{S}-\mathrm{methyl}-{ }^{2} \mathrm{H}_{3}\right]$ methionine can be compared directly, because both will include the contribution of any methionine recycling. Similarly, kinetics based on $[(\mathrm{m}+5)+(\mathrm{m}+4)]\left[\mathrm{U}-{ }^{13} \mathrm{C}\right]$ and $\left[1-{ }^{13} \mathrm{C}\right]$ methionine will include the $\mathrm{C}$ skeleton conserved in the methionine $\leftrightarrow$ homocysteine transformations.

\section{Statistics}

All data were compared by analysis of variance with animals $(n 4)$ treated as blocks throughout and analysed for effect of treatment $(n 2)$, isotope infusion $(n 2)$ and vascular fluids ( $n 2$ ). For comparisons of treatment (with or without choline plus creatine), analyses were performed separately for blood and plasma and for the two types of isotope infusion. This only allowed 3 residual df but if data comparisons between the two types of infusion (i.e. similar comparative isotopes, e.g. $\left[(\mathrm{m}+5)-\mathrm{U}-{ }^{13} \mathrm{C}\right]-$ and $\left[\mathrm{S}-\mathrm{methy}-{ }^{2} \mathrm{H}_{3}\right]$ methionine) showed no significant differences these were combined, with infusion used as a nested subblock to create 7 residual df. Similarly, for blood $v$. plasma analyses the effect of treatment was first determined and, if not significant, data were combined, with treatment used as a nested sub-block. These followed the principles and operation of Genstat 5 (1987). The mean values for the four hourly samples taken within each measurement period were used for statistical analysis and appropriate biological calculations.

\section{RESULTS}

Within treatments, whole-body ILR estimated from the $(m+5)$ ions of $U-{ }^{13} \mathrm{C}$-labelled algal and $\left[\mathrm{S}-\right.$ methyl- $\left.{ }^{2} \mathbf{H}_{3}\right]$ methionine infusions were not significantly different (Table 1). In contrast, the methionine ILR which includes recycling from homocysteine was significantly greater based on $\left[1-{ }^{13} \mathrm{C}\right]$ methionine mpe rather than the sum $[(\mathrm{m}+4)+(\mathrm{m}+5)]$ of relative enrichments derived from the labelled algae (Table 2). For both types of infusion, blood methionine was always of lower enrichment than plasma and, thus, ILR were correspondingly greater (Tables 1 and 2). In response to supplementation with choline plus creatine, both blood and plasma ILR based on non-recycled methionine were decreased by $18-25 \%$ with statistical significance between $P=0.091$ and $P=0.050$ (Table 1). If the data 
Table 1. Plasma and blood methionine irreversible-loss rates (ILR) assessed from either the relative enrichment of $[m+5]$ methionine or molar $\%$ excess (mpe) of $[S$ methyl- ${ }^{2} \mathrm{H}_{3}$ ]methionine in sheep administered either choline plus creatine or vehicle*

(Mean values for four animals)

\begin{tabular}{|c|c|c|c|c|}
\hline Treatment... & Control & $\begin{array}{l}\text { Choline } \\
\text { +creatine }\end{array}$ & SED & $\begin{array}{c}\text { Statistical } \\
\text { significance of } \\
\text { difference }{ }^{\prime}: P\end{array}$ \\
\hline \multicolumn{5}{|c|}{$\begin{array}{l}\operatorname{ILR}(\mu \mathrm{mol} / \mathrm{h}) \\
\quad\left[(\mathrm{m}+5)^{-19} \mathrm{C}\right] \text { methionine } \ddagger\end{array}$} \\
\hline Plasma & 1188 & 962 & $70 \cdot 8$ & 0.050 \\
\hline Blood§ & 1600 & 1357 & 80.9 & 0.058 \\
\hline \multicolumn{5}{|c|}{ [S-methyl-2 ${ }^{2} \mathrm{H}_{3}$ ]methionine $\ddagger$} \\
\hline Plasma & 1334 & 1023 & $112 \cdot 3$ & 0.069 \\
\hline Blood\$ & 1555 & 1279 & 112.5 & 0.091 \\
\hline
\end{tabular}

* For details of treatments and procedures, see pp. 48-50.

$\dagger$ By analysis of variance, with animals treated as blocks, comparisons between treatments based on 3 residual df.

\# For comparison between the ILR for the two different forms of isotope infusions there were no significant differences between treatments and the data were combined to increase the residual df to 7 . For plasma the comparisons $\left(\left[(\mathrm{m}+5)-{ }^{13} \mathrm{C}\right]\right.$ methionine v. $\left[\mathrm{S}\right.$-methyl- $\left.{ }^{2} \mathrm{H}_{3}\right]$ methionine) were 1075 v. $1178(\mathrm{SED} 76 \cdot 7) \mu \mathrm{mol} / \mathrm{h}$; $P=0.218$ and for blood $1479 v .1417$ (SED 83.5) $\mu \mathrm{mol} / \mathrm{h} ; P=0.483$.

$\$$ For blood $v$. plasma ILR comparisons combined across treatments $(7$ residual $\mathrm{df}):\left[(\mathrm{m}+5)-{ }^{13} \mathrm{C}\right] \mathrm{methionine}$ 1479 v. 1075 (SED 48.5) $\mu \mathrm{mol} / \mathrm{h} ; P<0.001 ;$ [S-methyl- ${ }^{2} \mathrm{H}_{3}$ ]methionine $1417 v .1178$ (SED 47.5 ) $\mu \mathrm{mol} / \mathrm{h} ; P<0.002$.

Table 2. Plasma and blood methionine irreversible-loss rates (ILR) assessed from either the combined relative enrichment of $[(m+4)+(m+5)]$ methionine ions or the molar \% excess (mpe) of $\left[1-{ }^{13} \mathrm{C}\right]$ methionine in sheep administered either choline plus creatine or vehicle*

(Mean values for four animals)

\begin{tabular}{|c|c|c|c|c|}
\hline Treatment... & Control & $\begin{array}{l}\text { Choline } \\
\text { + creatine }\end{array}$ & SED & $\begin{array}{c}\text { Statistical } \\
\text { significance of } \\
\text { difference } \dagger: P\end{array}$ \\
\hline \multicolumn{5}{|c|}{$\begin{array}{l}\text { ILR }(\mu \mathrm{mol} / \mathrm{h}) \\
\quad\left[(\mathrm{m}+4)+(\mathrm{m}+5)-{ }^{13} \mathrm{C}\right] \text { methionine } \ddagger\end{array}$} \\
\hline Plasma & 933 & 836 & $91 \cdot 0$ & $0 \cdot 364$ \\
\hline $\begin{array}{l}\text { Blood } \$ \\
{\left[1-{ }^{13} \text { C }\right] \text { methionine } \ddagger}\end{array}$ & 1144 & 1063 & $94 \cdot 0$ & 0.450 \\
\hline Plasma & 1262 & 1038 & $103 \cdot 7$ & $0 \cdot 119$ \\
\hline Blood§ & 1447 & 1294 & $84 \cdot 5$ & 0.169 \\
\hline
\end{tabular}

* For details of treatments and procedures, see pp. 48-50.

$\dagger$ By analysis of variance, with animals treated as blocks, comparisons between treatments based on 3 residual df.

$\$$ ILR $(\mu \mathrm{mol} / \mathrm{h}$ ) comparisons, within fluid and with treatments combined ( 7 residual df), between the two different forms of isotope infusion $\left(\left[(\mathrm{m}+4)+(\mathrm{m}+5)-{ }^{13} \mathrm{C}\right]\right.$ methionine $v$. [1- $\left.{ }^{13} \mathrm{C}\right]$ methionine $)$ were: plasma $884 v$. 1150 (SED 77.6); $P=0.011$; blood 1103 v. 1370 (SED 61.9); $P=0.004$.

$\S$ For blood $v$. plasma ILR comparisons across treatments $(7$ residual $\mathrm{df}):\left[(\mathrm{m}+4)+(\mathrm{m}+5)-{ }^{13} \mathrm{C}\right] \mathrm{methionine}$ 1103 v. 884 (SED 27.8 ) $\mu \mathrm{mol} / \mathrm{h} ; P<0.001 ;\left[1{ }^{13} \mathrm{C}\right]$ methionine $1370 v .1150$ (SED 55.1) $\mu \mathrm{mol} / \mathrm{h} ; P=0.005$. 
Table 3. Extent of re-methylation of homocysteine to methionine relative to methionine irreversible-loss rates (ILR) in sheep infused either with choline plus creatine or vehicle as assessed from $(m+4)$ and $(m+5)$ methionine $m / z$ ions following $U-{ }^{13} C$-labelled algal infusion or the comparative fluxes of $\left[1-{ }^{13} \mathrm{C}\right]$ methionine and $\left[S-\right.$ methyl- $\left.{ }^{2} \mathrm{H}_{3}\right]$ methionine through arterial blood and plasma*

(Mean values for four animals)

\begin{tabular}{|c|c|c|c|c|}
\hline Treatment... & Control & $\begin{array}{l}\text { Choline } \\
+ \text { creatine }\end{array}$ & SED & $\begin{array}{c}\text { Statistical } \\
\text { significance of } \\
\text { differencet: } P\end{array}$ \\
\hline \multicolumn{5}{|l|}{ ILR comparisons } \\
\hline \multicolumn{5}{|c|}{$[m+5]:[(m+4)+(m+5)]$ methionine } \\
\hline Plasma & $1 \cdot 268$ & $1 \cdot 197$ & $0 \cdot 0717$ & $0 \cdot 396$ \\
\hline Blood $f$ & $1 \cdot 401$ & $1 \cdot 308$ & 0.0486 & $0 \cdot 150$ \\
\hline \multicolumn{5}{|c|}{ [S-methyl- $\left.{ }^{2} \mathrm{H}_{3}\right]$ methionine: $\left[1-{ }^{13} \mathrm{C}\right]$ methionine } \\
\hline Plasma & 1.062 & 0.984 & 0.0309 & $0 \cdot 084$ \\
\hline Blood $\ddagger$ & 1.089 & 0.996 & $0 \cdot 0305$ & 0.056 \\
\hline \multicolumn{5}{|l|}{ Wool growth } \\
\hline Length $(\mathrm{mm} / \mathrm{d})$ & $0 \cdot 615$ & 0.529 & 0.029 & $0 \cdot 060$ \\
\hline Volume $\left(\mathrm{mm}^{3} \times 10^{-3} / \mathrm{d}\right)$ & $1 \cdot 167$ & 1.069 & $0 \cdot 035$ & 0.069 \\
\hline
\end{tabular}

* For details of treatments and procedures, see pp. 48-50.

$\uparrow$ By analysis of variance; animals treated as blocks; differences between treatments for 3 residual $\mathrm{df}$.

For plasma $v$. blood comparisons within infusion but with treatments combined (7 residual df): $[\mathrm{m}+5]:[(\mathrm{m}+4)+(\mathrm{m}+5)]$ methionine 1.233 v. 1.354 (SED 0.0139); $P<0.001 ;$ [S-methyl- $\left.{ }^{2} \mathrm{H}_{3}\right]$ methionine: $\left[1{ }^{13}\right.$ C]methionine, 1.023 v. $1.042(\operatorname{SED} 0.021) ; P=0.384$.

are combined for both infusions at each treatment then the effect was significant (both $P<0.005$; for 7 residual df) for plasma (1261 v. 992 (SED 63.5) $\mu \mathrm{mol} / \mathrm{h}$ ) and blood (1577 v. 1318 (SED 64.4) $\mu \mathrm{mol} / \mathrm{h}$ ). There was also a decrease in the flux which does not account for the recycling from homocysteine, but this was smaller in magnitude (7-18\%) and not statistically significant (Table 2) unless the data for both types of infusion were combined when, for plasma, the control $v$. treatment ILR were $1097 v .937$ (SED 68.2) $\mu \mathrm{mol} / \mathrm{h}$; $P=0.051$.

The minimum proportion of methionine flux which is recycled back to the amino acid from homocysteine can be assessed from the ILR ratios, [S-methyl- $\left.{ }^{2} \mathrm{H}_{3}\right]:\left[1-{ }^{13} \mathrm{C}\right]$ and $[\mathrm{m}+5]:[(\mathrm{m}+4)+(\mathrm{m}+5)]$ (Table 3). Both methods gave similar trends in response to administration of the methylated products but the magnitudes differed (Table 3 ). Thus, choline plus creatine supplementation led to a lowered value in both [S-methyl$\left.{ }^{2} \mathrm{H}_{3}\right]$ methionine: $\left[1-{ }^{13} \mathrm{C}\right]$ methionine ILR and $[\mathrm{m}+5]:[(\mathrm{m}+4)+(\mathrm{m}+5)]$ methionine following the $\mathrm{U}-{ }^{13} \mathrm{C}$-labelled amino acid hydrolysate. The changes bordered on statistical significance for the dual-methionine infusion but when combined with the algal infusions (to yield 7 residual $\mathrm{df}$ ) the values were lowered from 1.165 to 1.090 (SED 0.0362), $P=0.077$, for plasma and from 1.255 to 1.152 (SED 0.0307), $P=0.012$ for blood.

The magnitude of the remethylation (Table 3) was lower for the dual-isotope infusion, less than $10 \%$ of total methionine ILR, which contrasts with values of $25 \%$ based on [U$\left.{ }^{13} \mathrm{C}\right]$ methionine kinetics. The reasons for the difference in ILR which include recycling between the two methods are unclear. The relative enrichment of $\left[(\mathrm{m}+4)-{ }^{13} \mathrm{C}\right]$ methionine was approximately 0.05 the mpe of the $1-{ }^{13} \mathrm{C}$-labelled amino acid and even at the greater sensitivity allowed by the use of multiple label the accuracy and precision is correspondingly less. The $(m+5)$ fragment ion was 3-4 fold larger than the $(m+4)$ species and, thus, greater 
Table 4. Ratios of relative enrichments of $[(m+4)+(m+5)]:[m+5] m / z$ ions of free methionine in arterial, portal and hepatic blood and plasma from sheep infused with $U-{ }^{13} \mathrm{C}$-labelled algal hydrolysate and administered either vehicle or choline plus creatine and the tissue molar \% excess (mpe) of free $\left[1-{ }^{13} \mathrm{C}\right]$ methionine: $\left[S-\right.$ methyl $\left.-{ }^{2} \mathrm{H}_{3}\right]$ methionine in tissue fluids from sheep infused with vehicle*

(Mean values for four animals)

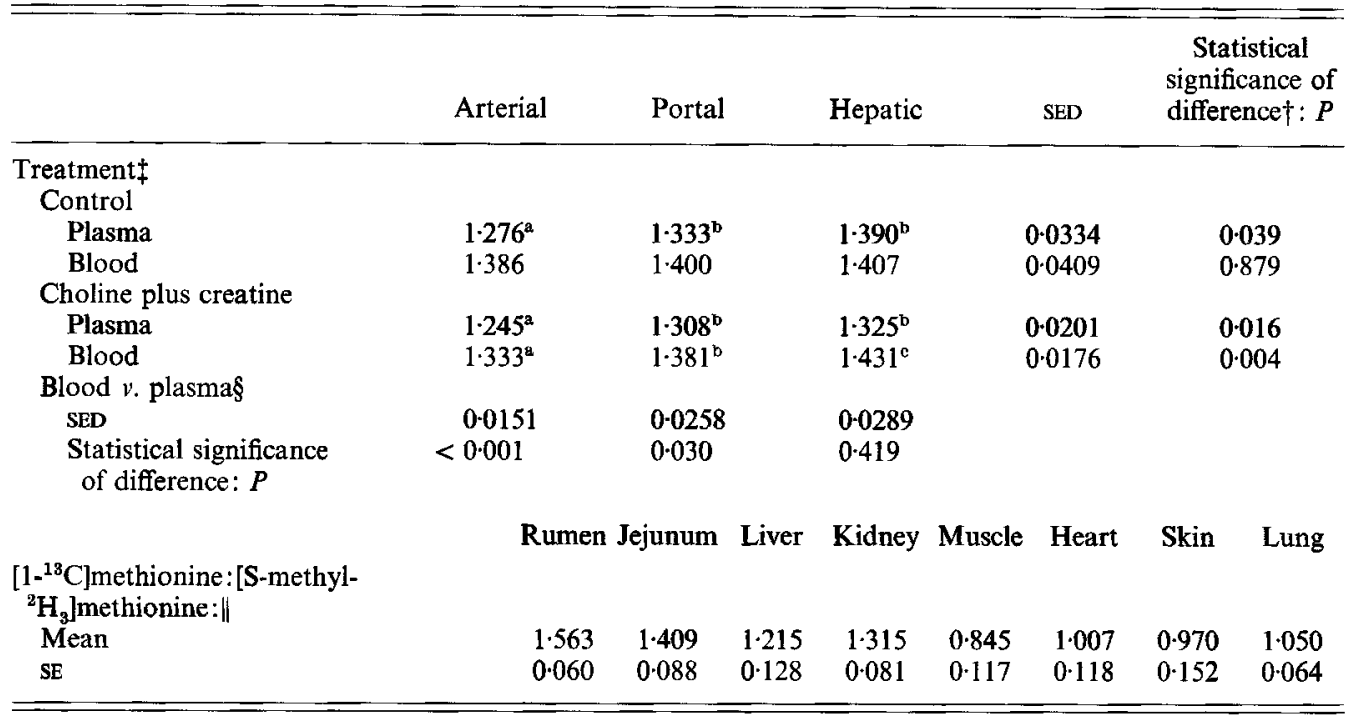

a, b, c Values with unlike superscripts within rows were significantly different $(P<0.05)$.

* For details of treatments and procedures, see pp. 48-50.

$\dagger$ By analysis of variance; for differences between sample sites with 6 residual df.

$\ddagger$ By analysis of variance there were no significant differences within sites and fluid type as a result of treatment ( 3 residual df).

$\S$ By analysis of variance, data combined between treatments, 7 residual df.

$\| n$ 4. Data based on a terminal infusion of equimolar quantities of $\left[1-{ }^{13} \mathrm{C}\right]$ methionine and [Smethyl- ${ }^{2} \mathrm{H}_{3}$ ]methionine followed by analysis of the respective mpe of the free methionine in tissue homogenate supernatant fluids (for details, see pp. 49-50).

confidence can be placed in the values from which the data in Table 1 are derived. In both instances, however, the extent of homocysteine methylation was greater, based on blood compared with plasma (Table 3).

Some indication of the tissues primarily responsible for the remethylation can be gauged from the change in ratios in blood (plasma) from different sites (Table 4). Thus, $[(m+4)+(m+5)]:[m+5]$ methionine relative enrichments were increased in blood from the hepatic portal vein and still further in hepatic venous fluids compared with that from the aorta. Terminal tissue analyses following the dual-isotope infusion added support to these observations in that $\left[1-{ }^{13} \mathrm{C}\right]:\left[\mathrm{S}-\right.$ methyl- $\left.{ }^{2} \mathrm{H}_{3}\right]$ methionine mpe was greatest in rumen, jejunal and hepatic tissues (Table 4). Of the other tissues, only for the kidney did the ratio substantially exceed that of the infusate, while values close to unity were recorded for skeletal muscle, heart, skin and lung.

Wool growth, either for length or volume, was not affected by treatment (Table 3), although the heterogeneous nature of wool fibres with the traditional northern UK crosses led to considerable variations in fibre diameter and shape compared with breeds specifically selected for wool quality. 


\section{DISCUSSION}

Under control conditions methionine ILR were greater than reported previously for sheep (933-1600 v. 510-880 $\mu \mathrm{mol} / \mathrm{h}$; Gill \& Ulyatt, 1979; Pisulewski \& Buttery, 1985), although the lower values from the literature were obtained with silage rations, known to be deficient in S-amino acids. To our knowledge no ruminant data in vivo are available on the rates of remethylation of homocysteine but Dawson et al. (1981) calculated that, with sheep, to provide sufficient methyl groups to account for choline turnover of $1.8 \mathrm{~g} / \mathrm{d}$ the equivalent of $9 \mathrm{~g} \mathrm{SAM}$ would be required, considerably in excess of the $2 \mathrm{~g}$ methionine absorbed daily. Their calculation assumed that no dietary choline was absorbed (Neill et al. 1979) and that all choline turnover involves synthesis from triethanolamine. In practice, much of the choline is recycled from phospholipids (Emmanuel \& Kennelly, 1984). A more realistic estimate is obtained from rates of choline oxidation and excretion and, as the former has been estimated at between 0 and $2 \%$ of choline flux in sheep and lactating goats (Neill $e t$ al. 1979; Emmanuel \& Kennelly, 1984), the use of these values would reduce methyl group requirements from $45 \mathrm{mmol} / \mathrm{d}$ (Dawson et al. 1981) to less than $1 \mathrm{mmol} / \mathrm{d}$. Such overestimates of methyl group requirements may also apply to calculations for the nonruminant (Mudd \& Pool, 1975), although for these species rates of choline oxidation considerably exceed those in ruminants (Ferger \& Vigneaud, 1950) due to greater activity of hepatic choline oxidase (EC 1.1.3.17; Xue \& Snoswell, 1986).

A greater drain on methylation status than choline turnover may involve urinary elimination of creatine and carnitine, resulting in losses of 8 and $0.8 \mathrm{mmol}$ methyl group equivalent per $d$ respectively (Henderson et al. 1983), proportionally similar to the losses in human subjects (Mudd \& Pool, 1975).

Together these minimum requirements are approximately $10 \mathrm{mmol} / \mathrm{d}$, within the reported values for methionine ILR, although other demands on SAM, e.g. syntheses of sarcosine, methylated amino acids etc. and DNA base methylation, have yet to be quantified. In human subjects the necessity for activation of the methionine-homocysteine cycle appears to be low as rates of remethylation, calculated from plasma kinetics, were only 8 and $17 \%$ of ILR in the fasted and fed condition respectively (Storch et al. 1988). Based on related methodology (the dual-isotope procedure rather than use of multi-labelled methionine), remethylation in the sheep appears to be of comparable magnitude, despite the poorer absorption of diet-based methyl groups. The values from the $\mathrm{U}-{ }^{13} \mathrm{C}$ kinetics were somewhat greater but remethylation was still less than $30 \%$ of methionine ILR. The index of methionine recycling in vitro for sheep liver slices yielded a similar low value (0.16), approximately one-third that observed for the rat (Xue \& Snoswell, 1985). This was attributed to the lower activity of betaine-homocysteine methyltransferase $(E C$ 2.1.1.5; BHT) in the ovine liver, with methionine cycling being equally dependent on 5-methyltetrahydrofolate-homocysteine methyltransferase (EC 2.1.1.13; MFHT; Xue \& Snoswell, 1985 , 1986). Both enzymes are distributed between ovine tissues; skeletal muscle contains $50 \%$ more of total MFHT activity than liver, although no BHT (Xue \& Snoswell, 1985). The greater amount of methionine recycling appears to be associated, however, with the splanchnic tissues, based on the changes observed for both vascular and tissue kinetics. No data appear to be available for activities of the enzymes in ovine GIT tissues, but the current results indicate these are major sites for methionine metabolism. Consequences of the short half-lives of GIT epithelial cells include requirements for synthesis of polyamines, products of SAM catabolism (Bardocz et al. 1989), and formate, derived from methionine transmethylations, for purine-base production (Boss, 1985). The importance of the liver in transmethylation reactions is long recognized as it is the primary site for phospholipid, sarcosine and creatine synthesis, while bile contains substantial quantities of choline. 
Thus, it appears that under nutritional conditions of energy and $\mathrm{N}$ equilibrium both human subjects and sheep exhibit similar rates of methionine recycling, despite the probable differences in methyl group supply from the diet. The remethylation of homocysteine can be suppressed, however, by provision of methyl group acceptors. Although not demonstrated for the sheep, in other mammals and chickens hepatic biosynthesis of creatine is inhibited by creatine provision (Walker, 1960). The mechanism does not appear to involve reduced activity of the guanidinoacetate methyltransferase (EC 2.1.1.2), but rather the preceding step of formation of the substrate guanidinoacetate is blocked proportionally. For this reason the amount infused was matched to normal urinary output (Henderson et al. 1983). The amount of choline infused $(4 \mathrm{mmol} / \mathrm{d})$ in the present study was approximately $25 \%$ of turnover (Dawson et al. 1981) and in excess of that normally oxidized (Neill et al. 1979). Thus, theoretically, synthesis in vivo should not be required. The changes in remethylation of homocysteine achieved suggest that first, unidirectional methionine ILR normally provides insufficient methyl groups to meet the demands of the animal and second, methionine cycling is sensitive to metabolic supply. In a converse situation addition of the methyl donor, betaine, to ovine liver slices increased the rate of methionine recycling (Xue \& Snoswell, 1985).

Although remethylation of homocysteine was inhibited by provision of the two methylated products, this only produced a small change in methionine ILR, which indicates that under the nutritional conditions employed cycling is not a major determinant of total flux. For the dual-isotope infusion there appeared to be complete suppression of recycling, which would fit with the hypothesis examined that provision of the major required methyl groups would reduce (eliminate) the need for a trans- and re-methylation cycle. The data on which these are based, however, are restricted to movements through blood and plasma. The transmethylation process occurs within the tissues and the exchange with the vasculature may alter under the experimental conditions employed, although the intracellular reactions may still continue, albeit at a different rate. To examine this further would require a terminal study, similar to that performed but where choline plus creatine are also infused. Another feature not monitored in the present study was whether the partition of ILR between protein synthesis and amino acid catabolism (through either the trans-sulphuration or transamination pathway) altered. The consecutive infusions of the $\mathrm{U}-{ }^{13} \mathrm{C}$-labelled algal hydrolysate and the dual-isotope mixture precluded measurement of methionine oxidation during the latter, although the lack of increase in wool growth might indicate that extra flows through the trans-sulphuration pathway did not occur. Alternatively, opportunities for increased anabolism might be restricted under conditions close to $\mathrm{N}$ equilibrium where the homeostatic rather than homeorhetic needs of the animal have to be met. In productive situations greater responses might be attained and, indeed, in lactating goats infusion of choline increased both milk protein concentration and content (Sharma \& Erdman, 1988). Even greater responses were observed when 2-amino-2-methyl1-propanol, an inhibitor of methylation of ethanolamine to choline, was administered. Reduction of methyl group flux demands on methionine metabolism, therefore, may offer production benefits to ruminants and might be easier to achieve by either nutritional or genetic manipulation rather than alteration of methionine supply.

The technical expertise of Mr A. G. Calder for the gas chromatography-mass spectrometry analyses is gratefully recognized. This study was financed by the Scottish Office Agriculture and Fisheries Department as part of the core budget to the Rowett Research Institute. D.K.R. was a recipient of a post-doctoral fellowship from the Charles and Annie Neumann Fellowship of Agriculture, The University of Western Australia. 


\section{REFERENCES}

Aurousseau, B., Connell, A., Revell, D. K., Rocha, H. J. G. \& Lobley, G. E. (1993). Hind-limb protein metabolism in growing sheep: effects of acute and chronic infusion of clenbuterol by close arterial and systemic routes. Comparative Biochemistry and Physiology 106C, 529-535.

Bardocz, S., Grant, G., Brown, D. S. \& Pusztai, A. (1989). Stimulation of polyamine synthesis and growth of the small intestine by dietary kidney bean lectin. In Recent Advances of Research in Antinutritional Factors in Legume Seeds, pp. 39-42 [J. Huisman, T. F. B. van der Poet and J. E. Liener, editors]. Wageningen: Pudoc.

Benevenga, N. J., Radcliffe, B. C. \& Egan, A. R. (1983). Tissue metabolism of methionine in sheep. Australian Journal of Biological Sciences 36, 475-485.

Boss, G. R. (1985). Cobalamin inactivation decreases purine and methionine synthesis in cultured lymphoblasts. Journal of Clinical Investigation 76, 213-218.

Calder, A. G. \& Smith, A. (1988). Stable isotope ratio analysis of leucine and ketoisocaproic acid in blood plasma by gas chromatography/mass spectrometry. Rapid Communications in Mass Spectrometry 2, 14-16.

Campbell, I. M. (1974). Incorporation and dilution values - their calculation in mass spectrally assayed stable isotope labelling experiments. Bioorganic Chemistry 3, 386-397.

Dawson, R. M. C., Grime, D. W. \& Lindsay, D. B. (1981). On the insensitivity of sheep to the almost complete microbial destruction of dietary choline before alimentary tract absorption. Biochemical Journal 196, 499-504.

Emmanuel, B. \& Kennelly, J. J. (1984). Kinetics of methionine and choline and their incorporation into plasma lipids and milk components in lactating goats. Journal of Dairy Science 67, 1912-1918.

Ferger, M. F. \& Vigneaud, V. (1950). Oxidation in vivo of the methyl groups of choline, betaine, dimethylthetin and dimethyl- $\beta$-propiothetin. Journal of Biological Chemistry 185, 53-57.

Finkelstein, J. D. \& Martin, J. J. (1984). Methionine metabolism in mammals. Distribution of homocysteine between competing pathways. Journal of Biological Chemistry 259, 9508-9513.

Genstat 5 (1987). Genstat 5 Reference Manual. Rothamsted Experimental Station. Oxford: Clarendon Press.

Gill, M. \& Ulyatt, M. J. (1979). The metabolism of methionine in silage-fed sheep. British Journal of Nutrition 41 , 605-609.

Henderson, G. D., Xue, G.-P. \& Snoswell, A. M. (1983). Carnitine and creatine content of tissues of normal and alloxan-diabetic sheep and rats. Comparative Biochemistry and Physiology 76B, 295-298.

Lobley, G. E., Connell, A., Revell, D. K., Brown, D. S. \& Calder, A. G. (1996). Mass and kinetic amino acid transfers across the ovine splanchnic bed: transport in blood and plasma, monitored through use of a multiple $\left[\mathrm{U}^{13} \mathrm{C}\right]$ amino acid mixture in response to choline plus creatine supplementation. British Journal of Nutrition (In the Press).

Mudd, S. H. \& Pool, J. R. (1975). Labile methyl balances for normal humans on various dietary regimens. Metabolism 24, 721-735.

Neill, A. R., Grime, D. W., Snoswell, A. M., Northrop, A. J., Lindsay, D. B. \& Dawson, R. M. C. (1979). The low availability of dietary choline for the nutrition of the sheep. Biochemical Journal 180, 559-565.

Pisulewski, P. M. \& Buttery, P. J. (1985). The effect of increasing methionine supply on the methionine conversion to cyst(e)ine in sheep. British Journal of Nutrition 54, 121-129.

Sharma, B. K. \& Erdman, R. A. (1988). Abomasal infusion of choline and methionine with or without 2-amino2-methyl-L-propanol for lactating dairy cows. Journal of Dairy Science 71, 2406-2411.

Storch, K. J., Wagner, D. A., Burke, J. F. \& Young, V. R. (1988). Quantitative study in vivo of methionine cycle in humans using [methyl- $\left.{ }^{2} \mathrm{H}_{3}\right]-$ and $\left[1-{ }^{13} \mathrm{C}\right]$ methionine. American Journal of Physiology 255, E322-331.

Walker, J. B. (1960). Metabolic control of creatine biosynthesis. 1. Effect of dietary creatine. Journal of Biological Chemistry 235, 2357-2361.

Xue, G.-P. \& Snoswell, A. M. (1985). Comparative studies on the methionine synthesis in sheep and rat tissues. Comparative Biochemistry and Physiology 80B, 489-494.

Xue, G.-P. \& Snoswell, A. M. (1986). Developmental changes in the activities of enzymes related to methyl group metabolism in sheep tissues. Comparative Biochemistry and Physiology 83B, 115-120. 